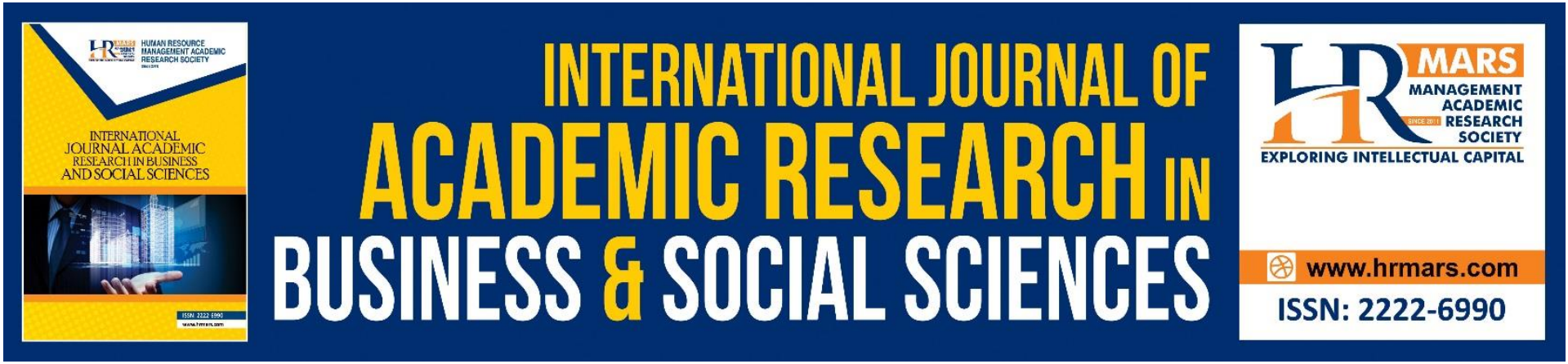

\title{
Financial Literacy among Malaysian Military Personnel
}

\section{Hafizah Mat Nawi, Hafez Shahril Hussin}

To Link this Article: http://dx.doi.org/10.6007/IJARBSS/v11-i2/8584

DOI:10.6007/IJARBSS/v11-i2/8584

Received: 17 December 2020, Revised: 16 January 2021, Accepted: 31 January 2021

Published Online: 20 February 2021

In-Text Citation: (Nawi \& Hussin, 2021)

To Cite this Article: Nawi, H. M., \& Hussin, H. S. (2021). Financial Literacy among Malaysian Military Personnel. International Journal of Academic Research in Business and Social Sciences, 11(2), 523-545.

Copyright: (c) 2021 The Author(s)

Published by Human Resource Management Academic Research Society (www.hrmars.com)

This article is published under the Creative Commons Attribution (CC BY 4.0) license. Anyone may reproduce, distribute, translate and create derivative works of this article (for both commercial and non-commercial purposes), subject to full attribution to the original publication and authors. The full terms of this license may be seen at: http://creativecommons.org/licences/by/4.0/legalcode

Vol. 11, No. 2, 2021, Pg. 523 - 545

Full Terms \& Conditions of access and use can be found at http://hrmars.com/index.php/pages/detail/publication-ethics 


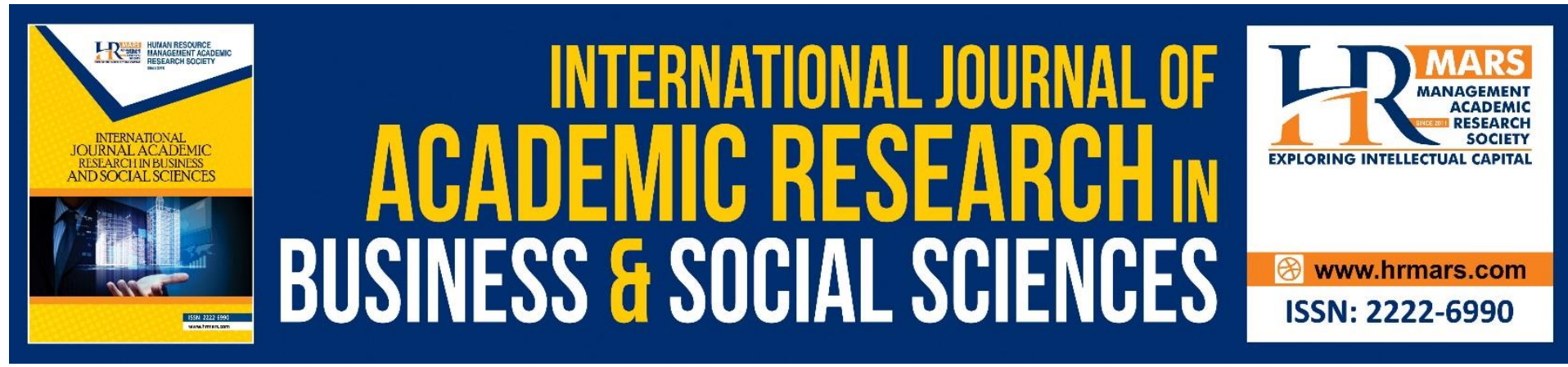

\title{
Financial Literacy among Malaysian Military Personnel
}

\author{
Hafizah Mat Nawi, Hafez Shahril Hussin \\ Faculty of Defence Studies and Management, Department of Defence Human \\ Resource Management, National Defence University of Malaysia, Malaysia. \\ Email: hafizah.matnawi@upnm.edu.my
}

\begin{abstract}
This study was carried out to investigate factors that affect the level of financial literacy among military members and the impacts thereof. The study also aims to find out is there any moderating factor(s) or mediator(s) that affect the relationship between financial literacy and its consequences. This study employed a qualitative method by implementing semistructured interviews with respondents engaged among 20 members of the Malaysian Armed Forces (MAF) and two experts. A model detailing the antecedents and consequences of financial literacy was developed. The data was analysed using the NVivo software to assign and group the interviewees' comments and thematic analysis was implemented to analyse the data collected. The findings revealed the following information: strong support for the proposed construct definition of financial literacy, identification of eight driving factors for the variable, financial inclusion as a moderating factor, and three perceived consequences of financial literacy. Furthermore, this study revealed additional items, which could be included in the existing constructs in order to expand the consequences of the focal construct. Generally, the findings stimulated will support the Malaysian government in achieving the aspirations detailed in the National Strategy for Financial Literacy 2019-2023. Specifically, the findings are useful for the Ministry of Defence Malaysia to develop and administer programmes geared towards improving personal financial management among military members, which is attributable to the goal set in the Five-Year Strategic Plan for the Ministry of Defence Malaysia. The findings of this study prepare a platform for future research to validate and expand the theoretical framework as presented in this research. The study is based on the qualitative data from the military members and certified financial planners, which can act as a basis for future research.
\end{abstract}

Keywords: Financial Literacy, Financial Planning, Financial Behaviour, Military Personnel, Malaysian Armed Forces (MAF)

\section{Introduction}

Financial literacy is undoubtedly beneficial for the general population as it aids the individuals to better manage their funds while ensuring a sufficient amount is channelled to support their daily life. Financially literate person has an understanding of budget, debt, credit, insurance and all other financial dimensions (Goyal \& Kumar, 2020). Accordingly, Mustapha and 
Jeyaram (2015) have asserted the particularly important status of a high financial literacy level is due to the complexity of today's marketplace. This underlines the need for everyone to understand the fundamentals of budgeting, savings, credit cards, investment activities, and other relevant financial tools or concepts. In general, financial literacy reflects the full and varied knowledge of possible risks and benefits associated with the topic, which enables one to organise and handle commercial data. Besides, it allows the derivation of sound judgments concerning financial planning, wealth accumulation, debt, and pensions.

In contrast, financial illiteracy can lead to a multitude of financial problems and consequences, such as mental illness, stress, lower self-esteem and miserable experiences. A low level of financial literacy is widespread in developing and developed countries alike (Lusardi \& Mitchell, 2011) as shown by a global financial literacy survey conducted by Klapper, Lusardi, and Van Oudheusden (2015). The aforementioned work has found that two-thirds of adults worldwide are financially illiterate, whereby other studies have attributed a low level of financial literacy, poor management of finance, and stressing over personal finance towards affecting the quality of financial decision-making and well-being (Delafrooz et al., 2010).

Moreover, having a financial problem further impacts an individual's daily life, which in turn lowers their job productivity (Delafrooz et al., 2010) and health (O'Neill et al., 2006). Based on these findings, Thaler (2013) has stressed that remedying the issue of financial illiteracy requires the undertaking of effective measures and viable solutions. Similarly, the general public should be properly educated regarding the importance of financial literacy and good financial management to ensure their financial well-being and an improved quality of life. However, Calcagno and Monticone (2015) have argued that a low level of financial literacy in different households does not necessarily equate bad financial decisions. In this case, the aspect of financial illiteracy may be improved by an expert's advice (Calcagno \& Monticone, 2015), which may become a disadvantage if their piece of advice endorsed is biased (Stoughton et al., 2011; Bergstresser et al., 2009).

To this end, financial literacy is equally useful for military members due to its role in ensuring sound short- and long-term financial decisions. Unfortunately, very few studies (Montegary, 2015; Carlson, Britt \& Goff, 2015; Bell et al., 2014) have looked into different financial-related issues among military members. Low levels of financial literacy among those of this particular population may affect national security as the hourseholds' financial decisions could affect the military deployments (Skimmyhorn, 2016). This weakness may further impede Malaysia's progress towards achieving the national vision aimed at ensuring a balanced distribution of income and wealth among all segments of the society. It is projected that such goal is attainable through a meaningful participation in competitive and productive growth processes alike.

Given the considerable impacts of personal financial mismanagement, an especially major concern emphasised is towards improving the level of financial literacy among the members of military, who are vital and tasked with national defence and security aspects. Therefore, this study seeks to validate the definition of financial literacy befitting the research context, while concomitantly examining the factors influencing the levels of financial literacy among the members of MAF. Additionally, it will look into the resultant impacts of personal financial management. 
The remainder of this paper is structured as follows accordingly. Section two will next present a review of the extant literature, followed by a discussion on the research propositions and methodology implemented in this work. Then, the interview findings are reported in a subsequent section, as well as discussing the implications and contributions following this work. Lastly, the last section contains a presentation of the conclusions obtained and the limitations encountered in this study, thereby offering recommendations for future research.

\section{Literature Review}

\section{Financial Literacy}

The earliest description offered by Noctor, Stoney and Strading (1992, p.4) refers to financial literacy as "the ability to make informed judgments and take effective decisions regarding the use and management of money". Alternatively, Organisation for Economic Co-operation and Development- OECD (2013) has delineated the term as a mix of knowledge, consciousness, talent, attitude, and conduct, which are collectively essential in making sound financial decisions and thus ensure one's personal financial happiness and security. Dam and Hotwani (2018) have classified variables of financial literacy into basic and advanced, whereby the basic variables include compound interest rate, inflation, risk, fixed deposit, tax filing and time value of money. Meanwhile, variables identified as advanced consist of stocks, mutual funds, diversification, superannuation and insurance. Collectively, most of the available studies have implemented a combination of basic and advanced variables both in measuring financial literacy.

Therefore, subsequent literature will present the contributing factors to financial literacy and their respective impacts on individual financial behaviours and planning towards achieving financial well-being.

\section{Contributing Factors to Financial Literacy}

A substantial number of studies identified demographic background, such as gender, marital status, age, human capital and income level, to influence the level of financial literacy of an individual. However, the findings are still unclear in terms of the directions of the relationships.

Many studies have found that men have a higher level of financial knowledge compared to women (see Kalmi and Ruuskanen, 2018; Bottazzi and Lusardi, 2016). The scholars have noted that most men generally obtain an adequate amount of financial knowledge before pursuing their tertiary education. In line with this, Furnham, Von Stumm and Fenton-O'Creevy (2015) have asserted that a majority of women has expressed their assumption of having someone in the future to manage their finances. Evidence of this notion can be observed in America, where men usually take charge make all financial decisions (Bongini, Trivellato and Zenga, 2015). Likewise, Fonseca et al. (2012) have looked into the role of gender gap in financial literacy, thus noting that men are more knowledgeable than women in terms of financial aspects as they are tasked with financial decision-making in their families. Therefore, men will develop their financial knowledge from time to time compared to women, who are placed in charge of household functions and nurturing roles (Bongini et al., 2015). Despite the inverse association between women and financial literacy, Wagland and Taylor's (2009) study on financial literacy among Australian undergraduate business students have revealed contradictory results. In particular, female students were found to answer correctly more 
frequently than the male counterparts, with an exception of the questions on estate planning and financial goals.

Additionally, Calamato (2010), asserts that individuals with low levels of financial literacy tend to encounter more risks in making financial decisions, potentially resulting in debt and imperilling the well-being of their relationship with others. In parallel with such evidence, Brown and Graf (2013) found that non-married individuals have a relatively low level of financial literacy as opposed to married persons. In contrast, married persons tend to have a high level of financial literacy since the debt problem is a major threat to marital happiness (Dew, 2016). Furthermore, a significant difference is observed between couples with children and those without. Pahl (2005) has asserted that couples without children tend to practise more independent money management. Alternatively, couples with children prefer to practise joint pooling system as they are more concerned with the budget and they tend to have a collective financial arrangement (Lauer and Yodanis, 2014). However, Servon and Kaestner (2008) found no significant differences between couples with children and their child-less counterparts in terms of financial literacy levels.

Interestingly, De Clercq and Venter (2009) have reported that an individual's financial literacy follows a life-cycle theory. The level of financial literacy increases as age increases. However, the positive relationship will stop when it reaches the age of 40 . The finding suggesting lower levels of financial literacy among younger and older individuals and higher levels among adults currently in the middle of their life cycle (Van Rooij et al., 2011; Lusardi and Mitchell, 2011). Meanwhile, Rootman and Antoni (2018) have found no significant relationships between age and financial literacy altogether.

Moreover, financial literacy is found to be lower among less-educated people and higher in educated individuals who have attended college or graduated from high school (Kalmi and Ruuskanen, 2018; Struwig et al., 2016). Besides, education background in relation specifically with 'finance' may differentiate the levels of financial literacy one displays, as well (Nano and Cani, 2013). Additionally, a high level of formal education can increase the level of financial literacy (Peng, Bartholomue, Fox, and Cravener, 2007) as this enhances one's tendency to be more responsible in their financial behaviours (Bernheim, Garrett, and Maki, 2001). Meanwhile, informal education related to finance may also influence the level of financial literacy that one has (Hira and Loibl, 2005).

Accordingly, previous studies have unearthed an association between income and financial literacy, specifically its lower rate among low-income earners (Kalmi and Ruuskanen, 2018). For example, Struwig et al. (2016) have found that those with high income and full-time employment have high financial literacy levels, which is also proven by Bhushan and Medury (2013) and De Clercq and Venter (2009) due to their similar findings. Besides, Rootman and Antoni (2018) have delineated a statistically significant relationship between financial literacy and income level, wherein their work shows that black consumers earning high-level income score a higher mean score for financial literacy compared to their peers earning less.

As far as the relationship with the motivation, financial socialisation and financial stress are concerned, these are the area where the least amount of research has been conducted. Previous research has attempted to explain the motivation using the force model and utility 
model by Vroom (1964) and Samuelson (1967), respectively; which focus on the role of expectancy, instrumentality, and valence or utility. In general, people are motivated by matters or things of good results. In tandem with such notion, Mandell and Klein (2007) have discovered a positive association between motivation and financial literacy. This is in a similar vein as Locke and Latham (2004).

Notwithstanding, the previous research agree that there tends to be changed in the nature of the relationship between financial literacy and financial socialisation. Accordingly, financial socialisation agents comprise of family members, peers at school or workplace, and media and culture (Kim and Chatterjee, 2013). Regardless, family is the most important agent of socialisation. As confirmed by Nawi et al. (2020), parents play a great role in influencing their offspring's consumer behaviours. This is attributable to children generally learning about financial management behaviours through observation, participation, or instructions from their parents. In particular, parental motivation for their sons and daughters differ; normally, they have higher hopes and expectations relating to job and savings for the sons, while daughters are taught and motivated to rely on them financially, especially during university days (Edwards, Allen and Hayhoe, 2007). Zhu (2018) had also affirmed the association. Zhu (2018) added that financial socialisation would lead to a positive impact on financial behaviour. Interestingly, each agent works differently throughout the life-cycle. Each person will interact and be exposed to numerous socialisation agents throughout their growth. Parental influence will grow weaker over time, whereas peer influence will become stronger (Sohn et al., 2012). Besides, media can also be one of the financial socialisation agents that may influence one's financial literacy (Sohn et al., 2012; Rootman and Antoni, 2018). In particular, Kim and Chatterjee's (2013) work has underlined the positive relationship between the extent to which people resort to media in search for financial information and practices.

Against the above discussion, at the same time, there has been a discussion by Smith and Weatherburn (2013) and O'Neill et al. (2006) for future research to focus on the influence of financial stress on financial literacy. Bongini and Zia (2018) argued that good savings habit and a proper way of managing money both can undoubtedly reduce one's financial stress. However, there is a limited study on the issue and there are unclear findings on the influence of financial behaviour on financial stress. Logically, stress may also affect the financial wellbeing. Ones would achieve life satisfaction when he/she experienced low financial stress and vice versa (Bernardo and Fernando-Resurreccion, 2018).

Following the above discussion and reasoning, the first research question can be formulated as follows:

RQ1: What are the factors that affect the level of financial literacy among military members?

\section{The Consequences of Financial Literacy}

It is envisaged that having identified contributing factors of financial literacy, this study will implicitly highlight the benefits to be gained by the military personnel. Financial literacy can function as the main predictor in financial behaviour establishment (Kim, Anderson, \& Seay, 2019). In particular, the success either at work or in their studies experienced by an individual may be influenced by their capability to manage their finances (Lusardi and Mitchell, 2014). Nevertheless, wise financial behaviour is arguably an essential component in defining and improving one's subjective and objective financial well-being concurrently (Joo, 2008; 
Garman and Forgue, 2006) in the context of income or assets and financial satisfaction, among others. Furthermore, a high level of financial literacy is generally seen in people who are also good at making financial plans, whether current or retirement plans (Lusardi and Mitchell, 2011). Financial planning will undoubtedly lead one towards their ultimate financial freedom. The sense of security this action imparts will indirectly satisfy their sense of financial well-being, which has been confirmed by Adam, Frimpong and Boadu (2017). Meanwhile, Tamaki (2011) and Grohmann et al. (2018) have claimed that financial literacy can result in an increased accessibility to finance, thus resulting in an improved financial behaviour and planning. Besides, financial literacy can strengthen the financial behaviours committed by an individual (Zulaihati et al., 2020), thus indirectly improving their sense of financial well-being. Financially literate people can utilise their inherent knowledge and are most likely capable of making wise judgments and well-informed savings decisions in order to avoid any debilitating financial affairs (Lusardi and Mitchell 2007).

This, in turn, will lead to a greater financial well-being (Taft et al., 2013). Consequently, the next questions in this study can be put forward as follows:

RQ2: What are the consequences of financial literacy?

RQ3: Is there any moderating factor(s) or mediator(s) that affect the relationship between financial literacy and its consequences?

\section{Research Propositions}

Other than to validate the definition of financial literacy, this study aims to investigate its antecedents and consequences. Based on the aforementioned extensive literature reviews with an emphasis on relevant areas such as financial literacy, financial awareness, financial behaviour and financial well-being, the study extracts eight driving factors of financial literacy, the moderating factor of financial inclusion and three perceived consequences of financial literacy.

Accordingly, financial literacy is influenced by the following factors, namely: (1) gender (Kalmi and Ruuskanen, 2018; Fonseca et al., 2012; Wagland and Taylor, 2009); (2) marital status (Dew, 2016; Brown and Graf, 2013; Van Rooij et al., 2011); (3) age (Struwig et al., 2016; De Clercq and Venter, 2009; Van Rooij et al., 2007); (4) human capital (Kalmi and Ruuskanen, 2018; Struwig et al., 2016; Nano and Cani; 2013); (5) income (Kalmi and Ruuskanen, 2018; Rootman and Antoni, 2018); (6) motivation (Mandell and Klein, 2007); (7) socialisation agent (Kim and Chatterjee, 2013); and (8) financial stress (Bongini and Zia, 2018; Bernardo and Fernando-Resurreccion, 2018).

Meanwhile, the consequences of financial literacy drawn from the available literature consist of the following: (1) financial planning (Lusardi and Mitchell, 2011); (2) financial behaviour (Zulaihati et al., 2020; Mandell and Klein, 2007); and (3) financial well-being (Taft et al., 2013; Van Rooij et al., 2011). Finally, the moderating factor of financial inclusion is elicited based on several previous studies reviewed, including Tamaki (2011).

\section{Research Methods and Analysis}

This study employed the exploratory research design due to two main reasons, namely: (i) there were no reliable measures available for the construct of financial literacy (Patton, 2002), and (ii) people of different settings would elicit dissimilar concepts and domains of financial 
capability (see Kempson et al., 2013). Therefore, this qualitative study implemented semistructured face-to-face interviews with respondents selected among the members of the MAF, which included the officers and Non-Commissioned Officers (NCOs) in three military services, namely the Malaysian Army, Royal Malaysian Navy (RMN), and Royal Malaysian Air Force (RMAF). The interviews were geared towards generating ideas underpinning the phenomenon of financial literacy (see Merriam, 1998) and obtaining general information detailing military personnel, financial facilities, and other financial-related issues.

Accordingly, the required data were collected through interviews with 22 respondents inclusive of two experts certified as financial planners, wherein the process was facilitated by the use of an interview guide. Regardless, the interviewees were allowed a sufficient margin in terms of how to reply these questions, as suggested by Bryman and Bell (2007). The interview sessions lasted between 20 and 40 minutes per respondent and the sessions with the experts and members of the MAF both were conducted in Malay language.

Next, this study employed NVivo software to assign and group the interviewees' comments in which a predetermined coding scheme was implemented to categorise the items reflecting the antecedents and consequences, regardless of whether they were consistent or different from those identified in the existing models. This was achieved by using the coder reliability check. Besides, two certified financial planners who participated in this exercise were asked individually to classify these factors into the constructs based on the delineated definitions. Following this, the responses obtained were listed and compared with the previously-sorted items (i.e. by the authors). Here, an identified theme affiliated with one or more of tentative themes with insufficient data extracted for its support would be disregarded. Meanwhile, collated extracts of data associated with the tentative theme was deemed as an indication of a new theme, whereby the developing theme was thus split into another theme. The calculations of the percentage of agreement between each pair of raters were done using a formula suggested by Goodwin and Goodwin (1985). Table 1 depicts the inter-rater reliability, which further assesses the antecedents and consequences of financial literacy. 
Table 1: Inter-rater reliability for antecedents and consequences of financial literacy Mean inter-rater reliability estimate

\begin{tabular}{ll}
\hline Antecedents & \\
Socialisation agents & 0.92 \\
Motivation & 0.82 \\
Financial stress & 0.76 \\
Consequences & \\
Financial planning & 0.70 \\
Financial behaviour & 0.88 \\
Financial well-being & 0.88 \\
\hline
\end{tabular}

The validity of the study findings obtained was established by comparing these findings with those available in the existing literature as suggested by Maxwell (1996). Besides, ensuring their accuracy in reflecting the phenomenon under study was done by testing for content validity, which was completed by the two certified financial planners. Based on the findings of the study, a new model of financial literacy was proposed.

\section{Findings}

\section{Financial Literacy Construct}

This study adopted a basic financial literacy measurement previously developed by Van Rooij et al. (2011) in which the questions encompassed topics related to numeracy, interest compounding, inflation, time value of money, and money illusion. The rationale of behind its usage was due to its well-fitting nature with the levels of financial knowledge reported by the respondents of this study, as suggested by Van Rooij et al. (2011). Some comments given by the participants are as follows:

'It seems to be a very good definition since it covers the interest and money illusion, whereby both elements are normally ignored by most of us.' (Army Major, 39 years old)

'I agree with these themes. It's a good definition of financial literacy. The questions are straightforward and very easy to understand.' (Army Lieutenant Colonel, 52 years old)

Generally, the respondents possessed a basic knowledge of finance and resorted to the use of simple financial management, especially in dealing with day-to-day financial needs. Most importantly, this measurement matched the opinions of experts. Accordingly, financial literacy was measured by a percentage of correct answers in knowledge tests, wherein each question was associated with the right answer as suggested by Van Rooij et al. (2011). Table 2 presents the themes and questions in basic literacy, which are adopted from Van Rooij (2011, p.452). 
Table 2: Themes and questions of financial literacy

\begin{tabular}{ll}
\hline Themes & Questions \\
\hline Numeracy & $\begin{array}{l}\text { "Suppose you had RM100 in a savings account and the interest rate was 2\% } \\
\text { per year. After } 5 \text { years, how much do you think you would have in the } \\
\text { account if you left the money to grow?" - Van Rooij (2011, p.452) }\end{array}$ \\
\hline $\begin{array}{l}\text { Interest } \\
\text { compounding }\end{array}$ & $\begin{array}{l}\text { "Suppose you had RM100 in a savings account and the interest rate is 20\% } \\
\text { years, how much would you have on this account in total?" - Van Rooij } \\
\text { (2011, p.452) }\end{array}$ \\
\hline Inflation & "Imagine that the interest rate on your savings account was 1\% per year \\
& $\begin{array}{l}\text { and inflation was 2\% per year. After 1 year, how much would you be able } \\
\text { to buy with the money in this account?"- Van Rooij (2011, p.452) }\end{array}$ \\
\hline Time value of & "Assume a friend inherits RM10,000 today and his sibling inherits RM10,000 \\
money & 3 years from now. Who is richer because of the inheritance?"- Van Rooij \\
& (2011, p.452) \\
\hline Money & "Suppose that in the year 2010, your income has doubled and the prices of \\
illusion & all goods have doubled too. In 2010, how much will you be able to buy with \\
& your income?"- Van Rooij (2011, p.452) \\
\hline
\end{tabular}

\section{Contributing Factors to Financial Literacy}

Concerning the antecedents of financial literacy as delineated in the research propositions, the qualitative data obtained offered valuable insight for each of the proposed linkages. Accordingly, eight factors influencing one's financial literacy were identified in this study, several of which were previously distinguished and discussed in earlier works. However, this study opted to bring all of the factors and incorporate them as ONE (1) single study. The factors represented different socio-demographic characteristics (i.e. gender, age, marital status, human capital and income level), motivation, socialisation agents, and financial stress.

\section{Socio-demographic Characteristics}

The respondents comprised of members of the national armed forces sampled from three different branches of armed services. Table 3 presents the socio-demographic backgrounds of the respondents. 
Table 3: Socio-demographic backgrounds of the respondents

\begin{tabular}{|c|c|c|}
\hline Factors & Items & Frequency \\
\hline \multirow[t]{2}{*}{ Gender } & Male & 16 \\
\hline & Female & 4 \\
\hline \multirow[t]{4}{*}{ Marital status } & Single & 7 \\
\hline & Married & 12 \\
\hline & Widowed & 0 \\
\hline & Separated/divorced & 1 \\
\hline \multirow[t]{4}{*}{ Age } & 24 or younger & 1 \\
\hline & $25-35$ & 6 \\
\hline & $36-45$ & 9 \\
\hline & $46-60$ & 4 \\
\hline \multirow[t]{5}{*}{ Human capital } & Lower than high school & 0 \\
\hline & High school & 5 \\
\hline & Undergraduate degree/diploma & 10 \\
\hline & Postgraduate degree/doctorate & 4 \\
\hline & Professional qualification & 1 \\
\hline \multirow{3}{*}{$\begin{array}{l}\text { Current rank (This factor is } \\
\text { used to obtain the information } \\
\text { on the respondents' income } \\
\text { level) }\end{array}$} & $\begin{array}{l}\text { Brigadier General and above/Naval First } \\
\text { Admiral and above }\end{array}$ & 0 \\
\hline & $\begin{array}{l}\text { Lieutenant Colonel/ Colonel/Naval } \\
\text { Commander/Naval Captain }\end{array}$ & 5 \\
\hline & Captain/ Major/Naval Lieutenant/Naval & 7 \\
\hline \multirow{5}{*}{$\begin{array}{l}\text { Note: The equivalent ranks for } \\
\text { Army and Air Force military } \\
\text { personnel are similar, EXCEPT } \\
\text { for the ranks of Naval } \\
\text { personnel, which are as } \\
\text { indicated }\end{array}$} & Lieutenant Commander & \\
\hline & $\begin{array}{l}\text { Lieutenant/ Second Lieutenant/Naval Sub- } \\
\text { Lieutenant/Naval Acting Sub-Lieutenant }\end{array}$ & 2 \\
\hline & Other Ranks - Sergeant and above/Naval & 3 \\
\hline & $\begin{array}{l}\text { Petty Officer and above } \\
\text { Other Ranks - Cornoral and below/Naval }\end{array}$ & 3 \\
\hline & & \\
\hline
\end{tabular}

Following various approaches highlighted in the literature, this study linked five sociodemographic characteristics, namely 'gender', 'marital status', 'age', 'human capital' and 'income level' with financial literacy. The results from the interviews conducted thus provided the evidence for such linkages.

\section{a. Gender.}

The results showed a significant difference between the levels of financial literacy of the male and female respondents. Males were found to be more knowledgeable than women in financial aspects as suggested by Fonseca et al. (2012).

'Making good savings is a worthwhile attitude, but spending money on goods is also important.' (Air Force Major, 42 years old, Male)

'To save money, I will put some cash in my bank account for future use. However, most of the time, I depend on my husband as he makes the financial decisions in the family.' (Army Captain, 35 years old, Female) 
The qualitative findings also show that men tend to develop their financial knowledge over time compared to women, who are usually in charge of household functions and assume the nurturing roles (Bongini et al., 2015).

'In case of financial difficulty, I will find extra money by doing a petty business on offduty days, while spending less on unnecessary things. The way I spend now is more economical compared to previous...due to commitment.' (Army Corporal, 31 years old, Male)

The results confirm the findings of several previous studies (see Kalmi and Ruuskanen, 2018; Bottazzi and Lusardi, 2016; Furnham et al., 2015; Van Rooij et al., 2011).

\section{b. Marital Status.}

Non-married individuals tend to have lower financial literacy levels compared to married persons (Brown and Graf, 2013) and vice versa. Married persons are more concerned with the various aspects of finance as they want to be more informed about such matters in order to avoid the debt problem, which is a major threat to marital happiness (Dew, 2016). Some of the respondents expressed the importance of savings, particularly to ensure quick and convenient access to finance for their families. Evidently, the financing patterns to vary depending on the number of dependents in the families.

'I just kept my extra money at home for easy future use and family security.' (Naval Chief Petty Officer, 41 years old, Married)

'I usually give extra money that I have to my wife to save for future use.' (Army Lieutenant, 29 years old, Married)

'I have six children and all of them are still studying at schools. I have learned a lot especially about managing money...I learn day by day, through experience.' (Army Major, 39 years old, Married)

\section{c. Age.}

The responses by the interviewees seemed to suggest that there is a relationship between the level of financial literacy and age. Some of them mentioned that their spending behaviours changed over time as their levels of financial literacy increased. This is in line with the findings of the study by De Clercq and Venter (2009) and Van Rooij et al. (2007). The following responses show different levels of financial literacy among different age groups of interviewees.

'I have a quite alarming spending problem. I tend to buy expensive ornaments and garments without a second thought.' (Air Force Lieutenant, 24 years old)

'I prefer to pay my utility bills and settle all financial commitments soon after getting a monthly salary.' (Air Force Captain, 35 years old)

'I will not tolerate any mistake in managing money. For instance, I will pay my credit card as soon as possible after using it, to avoid any interest charged.' (Army Lieutenant Colonel, 52 years old) 
In addition, interviewees stressed their anxiety over financial sustainability after retirement. One of them mentioned:

'I am 49 years old by the end of this year. For the next 11 years, I will be retiring. To prepare myself, I have to plan for my retirement days, for example, by buying properties and investing in several investment packages.' (Army Colonel, 49 years old)

The above issue is consistent with the argument of Milevsky and Salisbury (2006), who assert that retirees are burdened with investment returns risk and longevity risk. People may outlive their money, and financial literacy is very important in solving this particular problem.

\section{d. Human Capital.}

Both of the experts (i.e. the Certified Financial Planners - CFPs) affirmed that education, regardless of formal or informal, is vital to enhance an individual's level of financial literacy. The qualitative findings of this study have confirmed this association. There were six interviewees in the study who had attended the financial workshops conducted by the Malaysia Financial Planning Council (MFPC); their views of financial management were found to be quite different from the other interviewees.

'I am very careful about my financial matters, but when it comes to investing, I believe that we should take some risks. This is what I learned during my finance workshop.' (Naval Commander, 44 years old)

'I normally pay my credit card bills in full to avoid charges. I learned this after attending several financial workshops a few years ago.' (Army Warrant Officer 1, 46 years old)

Moreover, educated individuals are more likely to know the different types of financial resources (Lusardi and Mitchell, 2011). Such knowledge indirectly assists them in planning for either the current financial plan or retirement plan (Orth, 2006). As an example of the lack of financial knowledge, one of the interviewees has misunderstood the difference between investment and savings.

'I normally save extra cash that I have in an informal savings club like Kutu'; so that I will generate more money.' (Army Captain, 35 years old)

The CFP experts affirmed that 'Kutu' can encourage people to save, but not to generate money. On the other hand, financial literate individuals would prefer to invest or save money in financial institutions.

'I usually keep extra cash in my bank account for safekeeping and future use as a bank is insured by Bank Negara. So, whatever happened with the bank, our money is secured.' (Air Force Major, 42 years old)

Evidently, a respondent's education background that is related specifically to 'finance' may differentiate the level of financial literacy.

'I have a monthly budget that I usually follow to avoid overspending. This is quite easy for me as I studied accountancy during my university days.' (Army Colonel, 49 years old)

This agrees with several previous studies (see Nano and Cani, 2013; Peng et al., 2007).

\footnotetext{
${ }^{1}$ Kutu is an informal or rotating savings where a group of individuals (normally peers) agree to meet for a defined period in order to save.
} 


\section{e. Income Level.}

The CFP experts have suggested to the authors to measure the income level based on the current rank of the officers to maintain financial confidentiality. The varied responses received from interviewees include:

'I will try to earn extra money from a part-time job or I will borrow some money from my relatives. In the worst-case scenario, I will borrow from an informal money lender.' (Army Lance Corporal, 29 years old)

'I usually borrow some money from my friends or apply for a loan from the military co-operative.' (Air Force Flight Sergeant, 39 years old)

'I normally use my extra cash to buy luxury items.' (Army Warrant Officer 1, 46 years old)

'I do not have any savings as I always use all my salary for daily expenses and to pay debts.' (Naval Lieutenant Commander, 37 years old)

'In dealing with rising costs of living, personnel who has a meagre salary like me will normally use some savings, besides spending money according to basic needs.' (Naval Chief Petty Officer, 41 years old)

The above findings indicate that there was no significant difference between the high-income and low-income earners in managing their finance. However, the authors have maintained this factor in the model as suggested by the CFPs, and the findings of the existing literature.

\section{i. Motivation.}

Individuals are motivated by things that can lead to valued outcomes. The following were some of the responses:

'I have long-term written financial goals that I strive to achieve for many years. I am confident that I will be able to achieve the goals if I set my focus to them.' (Air Force Major, 42 years old)

'I have control over my financial aspects. I will never let them distract me in achieving success in my military career and personal life.' (Army Colonel, 49 years old)

'I set my long-term financial goals to be achieved in the future. I am confident that I will be able to achieve the goals sooner or later.' (Army Lieutenant Colonel, 48 years old)

These findings indicate that those who were highly motivated by their perceptions and awareness concerning financial stability in their life are more likely to be more financially literate. The findings support the study of Locke and Latham (2004).

\section{ii. Financial Socialisation Agents.}

As discussed in the literature, financial socialisation agents can be family members, friends, workplace, media and culture (Albeerdy and Gharleghi, 2015). The following responses show the influence of agents on interviewees' financial literacy. 
'Previously, my financial awareness was quite low. After joining Facebook and Instagram, I found my awareness level has increased.' (Air Force Captain, 35 years old)

'I prefer to work part-time during off duty days. I follow my good old friend who engages in a micro business.' (Naval Chief Petty Officer, 41 years old)

'Since I started this career, I had never faced any financial difficulties. I can surely control my monthly spending and personal budgeting. This is partly due to the military discipline that I learned.' (Army Major, 37 years old)

'Before buying any product, I will make a careful consideration of its use and whether I can afford it or not. I have this kind of behaviour since I was a child. It may be due to the discipline instilled by my parents.' (Air Force Major, 42 years old)

\section{iii. Financial Stress.}

Since this study is concerned with psychological stress as drawn primarily from the literature, the emphasis is on subjective perceptions as opposed to objective financial conditions. Some interviewees affirmed the influence of stress on financial awareness.

'In difficult situations, I will spend less and withdraw some money from my savings. If not, I will apply for an instant loan from military co-operative...Yes, sometimes difficulties can force us to search and read the information, as well as consulting qualified persons to reduce stress.' (Air Force Corporal, 32 years old)

'During the first 5 years of service, I suffered from depression after getting involved in financial difficulties. So, I sought advice from relevant officers in UGAT ${ }^{2}$ and other financial advice facilities in the service, and was able to overcome the problem. Two years ago, I got involved in another financial problem, but luckily I was not depressed because my awareness in finance has increased' (Army Major, 39 years old)

'I did not encounter any financial stress before, up until today since I have always planned for my spending and savings.' (Army Lieutenant Colonel, 45 years old)

The findings conform to the studies of Bongini and Zia (2018) and O'Neill et al. (2005), who also found the influence of financial behaviours on financial stress.

\section{Consequences of Financial Literacy}

Concerning the consequences of financial literacy, the majority of interviewees supported the fundamental views that financial literacy can lead to proper financial planning and good financial behaviours, and eventually the individuals' financial well-being. Responses were derived from interviews with respondents with high levels of financial literacy. They had commented on their financial behaviours and financial planning. One interviewee expressed his views as follows:

'Yes, I mean the key benefits of being financially literate are that, you'll always seeking advice when it involves a financial decision. Like me, I also prefer to compare and

\footnotetext{
2 UGAT is a Malay acronym of Urusan Gaji Angkatan Tentera or in English, The Armed Forces Payroll Directorate. It is one of the main directorates in the Malaysian Armed Forces Headquarters which is responsible for all matters relating to salaries and finance in the armed forces.
} 
contrast the interests either for a loan or for savings purposes. For instance, last month, I opened SSPN i-plus ${ }^{3}$ accounts for my kids as the scheme offers ---- such as savings for future education and insurance coverage.' (Naval Lieutenant, 44 years old)

Similarly, another interviewee argued that financial literacy would contribute to sound financial planning.

'I am very concerned about my financial security. If possible, I will try my best to achieve financial freedom. Therefore, I will always plan and spend accordingly. I will make sure that I have sufficient amount of money to cover living costs; while the same time having enough savings for emergencies and future use.' (Army Warrant Officer 1,46 years old)

The view was supported by an Air Force Captain (35 years old). His emphasis on financial planning was expressed as follows:

'We need to spend our money sparingly for personal satisfaction. A high level of financial awareness helps me in my financial planning, either for current or future use. I am serious in planning for investment, retirement other than pensions, as well as insurance for my family.

Interestingly, one interviewee commented on the importance of financial accessibility.

'Even though we have adequate literacy in finance, access to finance is also important for us to plan, spend or save. For example, in buying property, you should know whether it is for Bumiputras ${ }^{4}$ or Non-Bumiputras.' (Army Colonel, 49 years old)

\section{Discussion}

This study has derived several significant findings. The findings of the study indicate that the levels of financial literacy among the Malaysian military members follow the theory of planned behaviour (Fishbein and Ajzen, 1975), life-cycle theory (Penrose, 1952) and stress coping theory (Lazarus and Folkman, 1984). The individual's level of financial literacy was found to change significantly with objective (i.e. income) and subjective factors (i.e. age, marital status) during the various stages of his or her life. The levels of financial literacy among the participants also depend on their intentions to behave and they will act in accordance with their beliefs. This is in line with the argument of Ajzen and Fishbein (2005) who argue that human actions depend on behavioural belief, normative belief, and control belief. Besides, the findings follow the proposition of the stress-coping theory in relation to psychological stress.

Majority of the military members were found to encounter situations that require emergent financial expenditures, and they had to appraise the effects such expenditures might have on their well-being, both immediate and in a longer-term. The data obtained in this study present a pool of referencing items that could be incorporated into and improve the currently used instruments. These identified items can be included in the pool of influential factors that improve the extent of financial literacy within the MAF.

\footnotetext{
${ }^{3}$ SSPN-i Plus is a monthly savings plan designed by the National Higher Education Fund Corporation (PTPTN) with cheap and comprehensive takaful protection. The purpose is to save for higher education.

${ }_{4}$ Bumiputra is a Malay word which denotes the indigenous groups in Malaysia, predominantly the Malays and indigenous people of Sabah/Sarawak.
} 
Figure 1 presents a modified model based on the finding of the present study. The figure shows the antecedents (refer to \#1 and \#2) and consequences (refer to \#3, \#6 and \#7) of financial literacy. The model also presents the moderating factor of financial inclusion (refer to \#4), which affects the nature of the association between financial literacy and financial planning/financial behaviours. Additionally, the Figure indicates an association between the mediating factors (i.e. financial planning and financial behaviours) and financial stress (refer to \#5). The model also shows the mediating role of financial planning/financial behaviours (refer to \#6 and \#7) located between financial literacy and financial well-being, which explains the relationship between them (i.e. financial literacy and financial well-being).

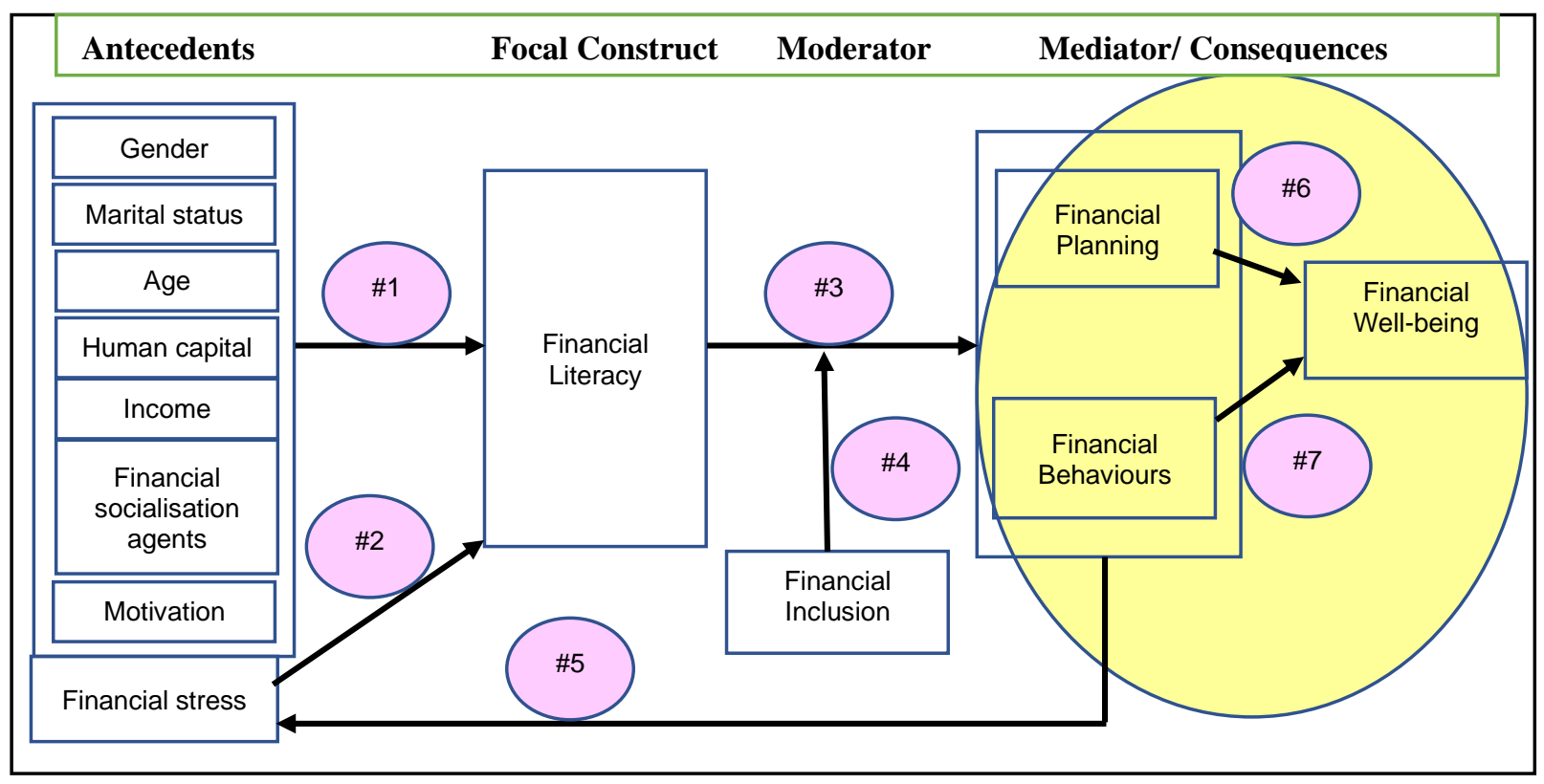

Figure 1. Modified Conceptual Model of Financial Literacy

\section{Implications and Contributions of The Study}

The findings of this study should encourage academics to adopt a more holistic conceptualisation of financial literacy by integrating such dimensions as financial stress, financial inclusion, financial behaviours, financial planning and financial well-being as additional elements into a model of antecedents and consequences of financial literacy. This study provides a definition of financial literacy that suits the circumstances associated with military personnel. Therefore, the contribution of this research is to offer a model of financial literacy from the perspective of military personnel (, which is different from the previous model developed from the non-military perspective). In fact, this research is the first study in Malaysia that attempts to find out the antecedents and consequences of financial literacy from the military perspective.

This study should also contribute to the body of literature on personal finance and help in creating awareness about good financial planning and management for the members of the armed forces and the society in general. The military personnel should recognise that financial exclusion would constrain them from making good financial decisions, as well as financial planning. They should take a positive initiative to improve their levels of financial literacy, which would indirectly improve their financial inclusion. These implications will objectify the 
government's aspiration as contained in the National Strategy for Financial Literacy 20192023; specifically in achieving the Strategic Priorities 2 to 5, which cover the financial accessibility on financial management information, tools and resources; instill positive behaviour among the military members; enhance the financial planning; and safeguard the wealth.

An understanding of financial behaviours and financial resiliency among members of the MAF can guide the policy-makers in formulating the relevant policies for the stakeholders. Relevant policies can contribute towards a better formulation of the national security system by strengthening and improving the defence and combat readiness of the armed forces. Specifically, the findings of this study should provide the Ministry of Defence Malaysia with a better understanding of the real problems faced by members of the armed forces concerning the financial literacy and financial predicaments, within the general goal of producing the more financially literate military personnel. The presence of influencing factors such as the financial stress and financial inclusion will improve the effectiveness of the policy-makers' efforts in assisting the military personnel to keep their peace of mind and a better concentration while on duty.

The findings should assist the Ministry in developing or administering personal financial improvement programmes for the benefit of the military members, per the government's aspiration as expressed in the Five-Year Strategic Plan 2016-2020 of the Ministry of Defence Malaysia. The plan calls for military members who are highly disciplined, dedicated, capable, resilient, financially independent, financially fit and free from any influence or vulnerabilities, which can be exploited by internal or external adversaries to the latter's advantage. All these qualities are required by professional members of the MAF in developing a credible fighting force, which is ready for any mission or duty to uphold the national sovereignty and territorial integrity of the country against any internal and external threat.

\section{Conclusions}

The construct definition of financial literacy presented in this study has been widely considered by interviewees to be valid and sound. This paper identifies the different factors that influence financial literacy. The findings indicate that apart from the socio-demographic characteristics, other factors such as the motivation, socialisation agent and financial stress can also influence the level of financial literacy. The findings also indicate that most of the interviewees are concerned with the mediating role of financial planning, as well as financial behaviours that lead to beneficial consequences; i.e. in terms of their financial well-being. Moreover, these qualitative findings found a moderating role of financial inclusion in strengthening the relationship between financial literacy and financial planning/financial behaviours.

The findings, implications and novelty of this study must be taken into consideration with certain limitations. The model developed in this research is a simple one, which is adapted from the various available models. Even though many predictors of financial literacy have been researched, other factors could have been used or could have been more useful. One more thing to consider is that, although after completing the process of reviewing the main assumptions, as well as inserting several subjective financing decisions' frameworks to the specifications of the models, the models need to be improved and refined so as to enable 
them to represent different scenarios. The conclusions of the study are dependent on the personal behaviours at a particular time, and any development after November 2018 may have to be disregarded.

However, the limitations do not reduce the importance of the findings. They prepare a platform for future research to validate and expand the theoretical framework as presented in this research. The study is based on the qualitative data from the military members and certified financial planners, which can act as a basis for future research. Future study is needed to compare the financial literacy of the Malaysian military personnel with those in other developing countries and investigate differences in order to enhance our knowledge about financing needs. The model can also be adopted with some modifications for a study of financial literacy among police personnel. It would also be useful to conduct a comparative study on the financial literacy of military and police forces as these two services have their distinctive characteristics arising from their legal status, authority and powers, and the extent of their closeness and involvement with the public.

\section{References}

Adam, A. M., Frimpong, S., \& Boadu, M. O. (2017). Financial literacy and financial planning: Implication for financial well-being of retirees. Business and Economic Horizons, 13(2), 224-236.

Ajzen, I., \& Fishbein, M. (2005). The influence of attitudes on behavior. The handbook of attitudes, 173(221), 31.

Albeerdy, M. I., \& Gharleghi, B. (2015). Determinants of the financial literacy among college students in Malaysia. International Journal of Business Administration, 6(3).

Arpana, D. (2020). Financial Literacy, Financial Behaviour and Financial planning:-Implication for financial wellbeing of professionals. International Journal of Psychosocial Rehabilitation, 24(6), 1271-1277.

Bell, M., Nelson, J., Spann, S., Molloy, C., Britt, S., \& Goff, B. (2014). The impact of financial resources on soldiers' well-being. Journal of Financial Counseling and Planning, 25.

Bergstresser, D., Chalmers, J. M., \& Tufano, P. (2009). Assessing the costs and benefits of brokers in the mutual fund industry. The Review of Financial Studies, 22(10), 4129-4156.

Bernardo, A. B., \& Fernando-Resurreccion, K. (2018). Financial stress and well-being of Filipino students: The moderating role of external locus-of-hope. Philippine Journal of Psychology, 51(1), 33-61.

Bernheim, B. D., Garrett, D. M., \& Maki, D. M. (2001). Education and saving: The long-term effects of high school financial curriculum mandates. Journal of public Economics, 80(3), 435-465.

Bhushan, P., \& Medury, Y. (2013). Financial literacy and its determinants. International Journal of Engineering, Business and Enterprise Applications, 4(2), 155-160.

Bongini, P., \& Zia, B. (2018). Introduction: The financial literacy collective. Economic Notes: Review of Banking, Finance and Monetary Economics, 47(2-3), 235-244.

Bongini, P., Trivellato, P., \& Zenga, M. (2015). Business students and financial literacy: When will the gender gap fade away? Journal of Financial Management, Markets and Institutions, 3(1), 13-30.

Bottazzi, L., \& Lusardi, A. (2016). Gender differences in financial literacy: Evidence from PISA data in Italy1. Global Financial Literacy Excellence Center (GFLEC) Working Paper, Washington $D C$. 
Brown, M., \& Graf, R. (2013). Financial literacy and retirement planning in Switzerland. Numeracy, 6(2), 6.

Bruhn, M., \& Love, I. (2014). The real impact of improved access to finance: Evidence from Mexico. The Journal of Finance, 69(3), 1347-1376.

Brune, L., Giné, X., Goldberg, J., \& Yang, D. (2016). Savings defaults and payment delays for cash transfers: Field experimental evidence from Malawi. The World Bank.

Bryman, A., \& Bell, B. (2007). Business research methods. UK: Oxford University Press.

Burgess, R., \& Pande, R. (2005). Do rural banks matter? Evidence from the Indian social banking experiment. American Economic Review, 95(3), 780-795.

Calamato, M. (2010). Learning financial literacy in the family (Master's thesis). Retrieved from ProQuest Dissertations and Theses database. (AAT 1488108)

Calcagno, R., \& Monticone, C. (2015). Financial literacy and the demand for financial advice. Journal of Banking and Finance, 50, 363-380.

Carlson, M. B., Britt, S. L., \& Goff, B. N. (2015). Factors associated with a composite measure of financial behavior among soldiers. Journal of Financial Counseling and Planning, 26(1), 30-42.

Dam, L. B., \& Hotwani, M. (2018). Financial Literacy: Conceptual Framework and Scale Development. SAMVAD, 15, 61-69.

De Clercq, B., \& Venter, J. M. P. (2009). Factors influencing a prospective chartered accountant's level of financial literacy: an exploratory study. Meditari Accountancy Research, 17(2), 47-60.

Delafrooz, N., Paim, L., Sabri, M. F., \& Masud, J. (2010). Effects of financial wellness on the relationship between financial problem and workplace productivity. World Applied Sciences Journal, 10(8), 871-878.

Demirguc-Kunt, A., Klapper, L., Singer, D., Ansar, S., \& Hess, J. (2018). The Global Findex Database 2017: Measuring financial inclusion and the fintech revolution. The World Bank.

Dew, J. P. (2016). Revisiting financial issues and marriage. In Handbook of consumer finance research (pp. 281-290). Springer, Cham.

Dupas, P., \& Robinson, J. (2013). Savings constraints and microenterprise development: Evidence from a field experiment in Kenya. American Economic Journal: Applied Economics, 5(1), 163-92.

Edwards, R., Allen, M. W., \& Hayhoe, C. R. (2007). Financial attitudes and family communication about students' finances: The role of sex differences. Communication Reports, 20(2), 90-100.

Fishbein, M., \& Ajzen, I. (1975). Belief, attitude, intention and behavior: An introduction to theory and research. Addison-Wesley, Reading, Mass.

Five Year Strategic Plan, 2016-2020. (2018). [online] Available at: $<$ http://www.mod.gov.my/en/mengenai-kami-7/strategic-plan/mindef-s-strategicplan.html> [Accessed 22 April 2019].

Fonseca, R., Mullen, K. J., Zamarro, G., \& Zissimopoulos, J. (2012). What explains the gender gap in financial literacy? The role of household decision making. Journal of Consumer Affairs, 46(1), 90-106.

Furnham, A., Von Stumm, S., \& Fenton-O'Creevy, M. (2015). Sex differences in money pathology in the general population. Social Indicators Research, 123(3), 701-711.

Garman, E. T., \& Forgue, R. E. (2006). Personal finance. Boston: Houghton Mifflin Company. 
Goodwin, L. D., \& Goodwin, W. L. (1985). An analysis of statistical techniques used in the Journal of Educational Psychology, 1979-1983. Educational psychologist, 20(1), 13-21.

Goyal, K., \& Kumar, S. (2021). Financial literacy: A systematic review and bibliometric analysis. International Journal of Consumer Studies, 45(1), 80-105.

Grohmann, A., Klühs, T., \& Menkhoff, L. (2018). Does financial literacy improve financial inclusion? Cross country evidence. World Development, 111, 84-96.

Grohmann, A., Kouwenberg, R., \& Menkhoff, L. (2015). Childhood roots of financial literacy. Journal of Economic Psychology, 51, 114-133.

Hira, T. K., \& Loibl, C. (2005). Understanding the impact of employer-provided financial education on workplace satisfaction. Journal of Consumer Affairs, 39(1), 173-194.

Joo, S. (2008). Personal financial wellness. In Handbook of consumer finance research (pp. 2133). Springer, New York, NY..

Kalmi, P., \& Ruuskanen, O. P. (2018). Financial literacy and retirement planning in Finland. Journal of Pension Economics \& Finance, 17(3), 335-362.

Kempson, E., Perotti, V., \& Scott, K. (2013). Measuring financial capability: a new instrument and results from low-and middle-income countries. World Bank.

Kim, K. T., Anderson, S. G., \& Seay, M. C. (2019). Financial knowledge and short-term and longterm financial behaviors of millennials in the United States. Journal of Family and Economic Issues, 40(2), 194-208. https://doi.org/10.1007/s1083 4-018-9595-2

Kim, J., \& Chatterjee, S. (2013). Childhood Financial Socialization and Young Adults' Financial Management. Journal of Financial Counseling \& Planning, 24(1).

Klapper, L., Lusardi, A., \& Van Oudheusden, P. (2015). Financial literacy around the world. Standard \& Poor's Ratings Services Global Financial Literacy Survey. Available from: http://media. mhfi.com/documents/2015-Finlit_paper_17_F3_SINGLES. pdf. Accessed 25 June 2019.

Lauer, S. R., \& Yodanis, C. (2014). Money management, gender and households. The Wiley Blackwell Companion to the Sociology of Families, 344-360.

Lazarus, R. S., \& Folkman, S. (1984). Coping and adaptation. The Handbook of Behavioral Medicine, 282325.

Locke, E. A., \& Latham, G. P. (2004). What should we do about motivation theory? Six recommendations for the twenty-first century. Academy of management review, 29(3), 388-403.

Lusardi, A., \& Mitchell, O. S. (2007). Baby boomer retirement security: The roles of planning, financial literacy, and housing wealth. Journal of Monetary Economics, 54(1), 205-224.

Lusardi, A., \& Mitchell, O. S. (2011). Financial literacy around the world: an overview. Journal of Pension Economics and Finance, 10(4), 497-508.

Lusardi, A., \& Mitchell, O. S. (2014). The economic importance of financial literacy: Theory and evidence. Journal of Economic Literature, 52(1), 5-44.

Malaysia Financial Planning Council, MFPC. (2004) RFP Module 1- Fundamentals of Financial Planning, 3rd ed., MFPC, Kuala Lumpur.

Mandell, L., \& Klein, L. S. (2007). Motivation and financial literacy. Financial Services Review, 16(2), 105.

Maxwell, J. A. (1996). Qualitative research design: An interactive approach. Thousand Oaks, California: Sage Publications.

Merriam, S. B. (1998). Qualitative Research and Case Study Applications in Education. Revised and Expanded from "Case Study Research in Education.". Jossey-Bass Publishers: San Francisco, CA 94104. 
Milevsky, M. A., \& Salisbury, T. S. (2006). Financial valuation of guaranteed minimum withdrawal benefits. Insurance: Mathematics and Economics, 38(1), 21-38.

Montegary, L. (2015). An army of debt: financial readiness and the military family. Cultural Studies, 29(5-6), 652-668.

Mustapha, M., \& Jeyaram, S. (2015). Financial literacy and demographic factors. Journal of Technology Management and Business, 2(1).

Nawi, H. M., Siong, O. H., \& Nee, C. Y. (2020). The Effects of Human Capital, Financial Socialisation Agents, and Motivation on Financial Literacy Among Private University Students In Malaysia. International Journal of Academic Research in Business and Social Sciences. 10(10), 159-168.

Nano, D., \& Cani, S. (2013). The differences in students' financial literacy based on financial education. Academicus International Scientific Journal, 2013(8), 149-160.

National Strategy for Financial Literacy 2019-2023. Available at: https://www.fenetwork.my/._Accessed 2 August 2019.

Niu, G., Zhou, Y., \& Gan, H. (2020). Financial literacy and retirement preparation in China. Pacific-Basin Finance Journal, 101262.

Noctor, M., Stoney, S., and Stradling, R. (1992). Financial literacy: a discussion of concepts and competences of financial literacy and opportunities for its introduction into young people's learning. Report prepared for the National Westminster Bank, National Foundation for Education Research, London.

O’Neill, B., Prawitz, A., Sorhaindo, B., Kim, J., \& Garman, E. T. (2006). Changes in health, negative financial events, and financial distress/financial well-being for debt management program clients. Financial Counseling and Planning, 17(2), 46-63.

OECD (Organisation for Economic Cooperation and Development). (2013). OECD/INFE toolkit to measure financial literacy and financial inclusion: Guidance, core questionnaire and supplementary questions. Available from:

http://www.oecd.org/daf/fin/financialeducation/TrustFund2013_OECD_INFE_toolkit_ to_measure_fin_lit_and_fin_incl.pdf. Accessed 14 March 2019.

Orth, B. J. (2006). Managing longevity risk in US retirement plans through mandatory annuitization. North American Actuarial Journal, 10(3), 32-44.

Pahl, J. (2005). Individualisation in couple finances: who pays for the children?. Social Policy and Society, 4(4), 381-391.

Patton, M. Q. (2002). Two decades of developments in qualitative inquiry: A personal, experiential perspective. Qualitative Social Work, 1(3), 261-283.

Peng, T. M., Bartholomew, S., Fox, J. J., \& Cravener, G. (2007). The impact of personal financial education delivered in high school and college courses. Journal of Family and Economic Issues, 28, 265-284.

Penrose, E. T. (1952). Biological analogies in the theory of the firm. The American Economic Review, 42(5), 804-819.

Rootman, C., \& Antoni, X. (2018). Demographic factors affecting the financial literacy of black consumers: critical research in South Africa. In The 2018 Annual Conference of the Emerging Markets Conference Board (p.215-230). Wits Business School.

Samuelson, P. (1967). Economics. New York: McGraw-Hill Book Co.

Servon, L. J., \& Kaestner, R. (2008). Consumer financial literacy and the impact of online banking on the financial behavior of lower-income bank customers. Journal of Consumer Affairs, 42(2), 271-305. 
Skimmyhorn, W. L. (2016). Comparing military and civilian household finances: Descriptive evidence from recent surveys. Journal of Consumer Affairs, 50(2), 471-483.

Smith, N., \& Weatherburn, D. (2013). Personal stress, financial stress, social support and women's experiences of physical violence: A longitudinal analysis. BOCSAR NSW Crime and Justice Bulletins, 20.

Sohn, S. H., Joo, S. H., Grable, J. E., Lee, S., \& Kim, M. (2012). Adolescents' financial literacy: The role of financial socialization agents, financial experiences, and money attitudes in shaping financial literacy among South Korean youth. Journal of Adolescence, 35(4), 969-980.

Stoughton, N. M., Wu, Y., \& Zechner, J. (2011). Intermediated investment management. The Journal of Finance, 66(3), 947-980.

Struwig, J., Roberts, B., \& Gordon, S. (2016). Financial Literacy in South Africa: Results from the 2015 South African Social Attitudes Survey round. Report prepared by the Human Sciences Research Council (HSRC) on behalf of the Financial Services Board (FSB). Pretoria: Financial Services Board.

Taft, M. K., Hosein, Z. Z., Mehrizi, S. M. T., \& Roshan, A. (2013). The relation between financial literacy. Financial wellbeing and financial concerns. International Journal of Business and Management, 8(11), 63-75.

Tamaki, R. (2011). OCED-FSB Conference on financial literacy: Financial education for all. Ministry of Finance, Republic of South Africa.

Thaler, R. H. (2013). Financial literacy, beyond the classroom. The New York Times.

Utkarsh, U., Pandey, A., Ashta, A., Spiegelman, E., \& Sutan, A. (2020). Catch Them Young: Impact of Financial Socialization, Financial Literacy and Attitude Toward Money on Financial Well-being of Young Adults. International Journal of Consumer Studies.

Van Rooij, M., Lusardi, A., \& Alessie, R. (2007). Financial literacy and stock market participation (No. w13565). National Bureau of Economic Research.

Van Rooij, M., Lusardi, A., \& Alessie, R. (2011). Financial literacy and stock market participation. Journal of Financial Economics, 101(2), 449-472.

Vroom, V. H. (1964). Work and Motivation. New York: John Wiley \& Sons.

Wagland, S. P., \& Taylor, S. (2009). When it comes to financial literacy, is gender really an issue? Australasian Accounting, Business and Finance Journal, 3(1), 3.

Zhu, A. Y. F. (2018). Parental socialization and financial capability among chinese adolescents in Hong Kong. Journal of Family and Economic Issues, 39(4), 566-576. https://doi.org/10.1007/s1083 4-018-9584-5.

Zulaihati, S., Susanti, S., \& Widyastuti, U. (2020). Teachers' financial literacy: Does it impact on financial behaviour?. Management Science Letters, 10(3), 653-658. 